\title{
Magnetic spectroscopy of nanoparticulate greigite, Fe3S4.
}

DOI:

10.1180/minmag.2016.080.114

\section{Document Version}

Accepted author manuscript

Link to publication record in Manchester Research Explorer

\section{Citation for published version (APA):}

Pattrick, R., Coker, V., Akhtar, M., Malik, M., Lewis, E., Haigh, S., O'Brien, P., Shafer, P. C., \& van der Laan, G. (2016). Magnetic spectroscopy of nanoparticulate greigite, Fe3S4. Mineralogical Magazine.

https://doi.org/10.1180/minmag.2016.080.114

\section{Published in:}

Mineralogical Magazine

\section{Citing this paper}

Please note that where the full-text provided on Manchester Research Explorer is the Author Accepted Manuscript or Proof version this may differ from the final Published version. If citing, it is advised that you check and use the publisher's definitive version.

\section{General rights}

Copyright and moral rights for the publications made accessible in the Research Explorer are retained by the authors and/or other copyright owners and it is a condition of accessing publications that users recognise and abide by the legal requirements associated with these rights.

\section{Takedown policy}

If you believe that this document breaches copyright please refer to the University of Manchester's Takedown Procedures [http://man.ac.uk/04Y6Bo] or contact uml.scholarlycommunications@manchester.ac.uk providing relevant details, so we can investigate your claim.

\section{OPEN ACCESS}




\title{
Magnetic spectroscopy of nanoparticulate greigite, $\mathrm{Fe}_{3} \mathrm{~S}_{4}$.
}

Richard A D Pattrick ${ }^{1,2}$, Victoria S Coker ${ }^{1.2}$, Masood Akhtar ${ }^{3}$, Edward Lewis ${ }^{4}$, Sarah Haigh ${ }^{4}$, Paul $\mathrm{O}^{\prime}$ Brien ${ }^{4}$, Padraic C Shafer ${ }^{5}$ and Gerrit van der Laan ${ }^{6}$.

\section{Affiliations}

${ }^{1,2}$ School of Earth, Atmospheric and Environmental Sciences and Williamson Research Centre, The University of Manchester, M13 9PL, United Kingdom

${ }^{3}$ School of Chemistry, The University of Manchester, Manchester, M13 9PL, United Kingdom

${ }^{4}$ School of Materials, The University of Manchester, Manchester, M13 9PL, United Kingdom

${ }^{5}$ Advanced Light Source, Lawrence Berkeley National Labs,. Berkeley, CA USA

${ }^{6}$ Magnetic Spectroscopy Group, Diamond Light Source, Didcot OX11 ODE, United Kingdom

\begin{abstract}
Synthesis of $\mathrm{Ni}$ and $\mathrm{Zn}$ substituted nano-greigite, $\mathrm{Fe}_{3} \mathrm{~S}_{4}$, is achieved from single source diethyldithiocarbamato precursor compounds, producing particles typically 50-100 nm in diameter with plate-like pseudohexagonal morphologies. Up to $12 \mathrm{wt} \% \mathrm{Ni}$ is incorporated into the greigite structure, and there is evidence that $\mathrm{Zn}$ is also incorporated but Co is not substituted into the lattice. The Fe $L_{3} \mathrm{X}$-ray absorption spectra (XAS) for these materials have a narrow single intensity at $707.7 \mathrm{eV}$ and the resulting main X-ray magnetic circular dichroism (XMCD) has the same sign .at $708.75 \mathrm{eV}$. All XMCD spectra also have a broad positive feature at $711 \mathrm{eV}$, a characteristic of covalent mixing. The greigite XMCD spectra contrast with the three clearly defined XMCD site specific peaks found in the ferrite spinel, magnetite. The Fe $L_{2,3}$ XAS and XMCD spectra of the greigite reflect and reveal the high conductivity of greigite and the very strong covalency of the Fe$\mathrm{S}$ bonding. The electron hopping between $\mathrm{Fe}^{3+}$ and $\mathrm{Fe}^{2+}$ on octahedral sites results in an intermediate oxidation state of the $\mathrm{Fe}$ in the $\mathrm{O}_{\mathrm{h}}$ site of $\mathrm{Fe}^{2.5+}$ producing an effective formula of $\left.\left[\mathrm{Fe}^{3+} \uparrow\right]_{\mathrm{A}-\text { site }}\left[2 \mathrm{Fe}^{2.5+} \downarrow\right]_{\mathrm{B}-\text { site }} \mathrm{S}_{4}{ }^{2-}\right]$. The $\mathrm{Ni} L_{2,3} \mathrm{XAS}$ and XMCD reveal substitution on the $\mathrm{O}_{\mathrm{h}}$ site with a strongly covalent character and an oxidation state $<\mathrm{Ni}^{1.5+}$ in a representative formula $\left[\mathrm{Fe}^{3+} \uparrow\right]_{\mathrm{A}}$ $\left[\left[(2-\mathrm{x}) \mathrm{Fe}^{2.5+} \downarrow\right]\left[\mathrm{Ni}_{\mathrm{x}}{ }^{1.5+}\right]\right]_{\mathrm{B}} \mathrm{S}_{4}{ }^{2-}$.
\end{abstract}




\section{Introduction}

Greigite $\left(\mathrm{Fe}_{3} \mathrm{~S}_{4}\right)$ is a ferrimagnetic thiospinel of environmental importance and technological potential. The magnetic and electronic properties of greigite with its structural similarity to the much exploited magnetite $\left(\mathrm{Fe}_{3} \mathrm{O}_{4}\right)$ have attracted increasing interest for future technological exploitation. This interest has been boosted by the successful development of stoichiometric nano-greigite materials (Han and Gao, 2008; Aktar et al., 2011) and, for instance, promising tests using greigite nanoparticles in cancer hyperthermia treatments (Chang et al., 2011). Greigite is present in nature in recent and Quaternary reducing sediments formed by either microbially mediated or authigenic diagenetic processes involving sulfate reduction; it is often a metastable precursor to pyrite (Skinner et al. 1964; Roberts and Weaver, 2005; Rowan et al, 2009). As a microbial biomineral, greigite is formed in magnetotactic bacteria that thrive at sub-surface redox interfaces, developing as intracellular single domain crystals (Mann et al., 1990; Schuler and Frankel, 1999) which can be preserved for up to a few million years (Vasiliev et al, 2008). Although its metastability in near surface environments leads to both oxidative breakdown and pyritisation, greigite has also been recorded in Cretaceous sedimentary sequences (Reynolds et al., 1994). The ferrimagnetic properties and the ability to retain a permanent magnetic signature of greigite means it is used in palaeomagnetic investigations that inform magnetic reversals, magnetostratigraphy, magnetic palaeointensity and palaeoclimatic studies (Roberts et al., 2005; Snowball and Torii , 1999; Frank et al, 2007). Greigite is of further interest as it is found in seafloor hydrothermal systems where it has been implicated in enzyme formation as a precursor for early life (Schoonen and Barnes, 1991; Russell et al., 2005).

There is significant interest in doping of nanomaterials and thin films as a method of tuning properties such as band gap (Erwin et al., 2005; Wang, et al., 2006) and molecular precursors offer a facile and efficient method of achieving this as recently demonstrated for $\mathrm{Cr}$-doped molybdenum disulfide $\left(\mathrm{MoS}_{2}\right.$ ) (Lewis et al., 2015). The present study examines the production of nano-greigite using molecular precursors (see also Vanitha and O'Brien, 2008; Akhtar et al., 2011) and the doping of greigite by $\mathrm{Co}, \mathrm{Ni}$ and $\mathrm{Zn}$ to examine the tunability of its electrical and magnetic properties. Here the magnetic and electronic structure of the greigite products is examined using X-ray absorption spectroscopy (XAS) and the resulting X-ray magnetic circular dichroism (XMCD) allowing comparison with magnetite and other ferrite spinels. The XMCD technique has been used with great success in the study of magnetite and other nano-particulate ferrite spinels (Coker et 
al., 2008) but the sparse studies of greigite have produced baffling XMCD signals (Letard et al., 2005; Chang et al., 2012a).

\section{Structure and magnetism}

Greigite $\left(\mathrm{Fe}_{3} \mathrm{~S}_{4}\right)$ has an inverse spinel crystal structure (Figure 1) with a space group $\mathrm{Fd} 3 \mathrm{~m}$ and is isostructural with the ferrite oxide spinel, magnetite $\left(\mathrm{Fe}_{3} \mathrm{O}_{4}\right)$. Theoretically, a unit cell of greigite comprises $1 / 3$ of the Fe atoms as $\mathrm{Fe}^{3+}$ in tetrahedral coordination (the $\mathrm{A}$ site; $\mathrm{Fe}^{3+} \mathrm{T}_{\mathrm{d}}$ ) and $2 / 3$ of the $\mathrm{Fe}$ atoms are in octahedral coordination, split equality between $\mathrm{Fe}^{2+}$ and $\mathrm{Fe}^{3+}$ (the $\mathrm{B}$ site; $\mathrm{Fe}^{2+} \mathrm{O}_{\mathrm{h}}$ and $\mathrm{Fe}^{3+} \mathrm{O}_{\mathrm{h}}$, respectively) (see Roldan et al., 2013).

Greigite has a collinear ferrimagnetic spin arrangement with antiferromagnetic coupling between the octahedral (B site) and tetrahedral (A site) ions (Chang et al., 2008; 2009a; 2009b) represented by the formula $\left[\mathrm{Fe}^{3+} \uparrow\right]_{\mathrm{A}}\left[\mathrm{Fe}^{2+} \downarrow \mathrm{Fe}^{3+} \downarrow\right]_{\mathrm{B}} \mathrm{S}_{4}{ }^{2-}$. The easy axis of magnetization is $<111>$ (Yamaguchi and Wada, 1970; Heywood et al., 1991) and the average magnetic moments of the A and B sites at room temperature, determined by neutron diffraction, are $3.0 \mu_{\mathrm{B}}$ (Chang et al. 2008) producing a net magnetic moment of $3.0 \mu_{\mathrm{B}}$ per formula unit; a net magnetic moment of $3.5 \mu_{\mathrm{B}}$ was recorded in stoichiometric greigite nanoparticles (Lyubutin et al., 2013), and a saturation magnetism of 59 A $\mathrm{m}^{2} \mathrm{~kg}^{-1}$. There is no evidence of significant vacancy concentration or spin canting in pure greigite (Dunlop and Özdemir, 1997; Chang et al., 2008).

Although isostructural with magnetite, the different anions and increased covalency in greigite means there are significant differences in the properties of magnetite (Roberts et al., 2011). For example, greigite has a different easy axis of magnetization $(<111>$ in magnetite compared to $<100>$ in greigite) (Dunlop and Özdemir, 1997) and there is a three times lower exchange coupling between the Fe in tetrahedral and octahedral sites in greigite compared to magnetite (Chang et al., 2008, Devey et al., 2009), although this should not affect the antiferromagnetic ordering in the two minerals (Roberts et al. 2011). The $K_{1}$ (anisotropy constant) value for single domain greigite is $2.9 \pm 0.2 \times 10^{4} \mathrm{~J} \mathrm{~m}^{-3}$ is higher than that of magnetite $\left(1.35 \times 10^{4} \mathrm{~J} \mathrm{~m}^{-3}\right)$ which may explain the higher coercivity of $>60 \mathrm{mT}$ in equidimensional single-domain greigite, compared to $\sim 20 \mathrm{mT}$ for magnetite (Dunlop and Özdemir, 1997; Chang et al., 2012b; Dekkers et al., 2000). In addition, there is no observed Verwey transition in greigite, consistent with the ab-initio DFT calculations of Devey et al. (2009). Lyubutin et al. (2013) explain differences in the optical MCD spectra of greigite 
compared to magnetite by "electron excitations in a wide band with superimposed peaks of the $d-$ $d$ transitions in Fe ions".

\section{Greigite chemistry and electronic structure}

Greigite, $\mathrm{Fe}_{3} \mathrm{~S}_{4}$, is a member of the linnaeite mineral group of isostructural Fe-Co-Ni thiospinels, the other end-members being linneaite, $\mathrm{CO}_{3} \mathrm{~S}_{4}$ and siegenite, $\mathrm{Ni}_{3} \mathrm{~S}_{4}$. Solid solutions are limited, with almost no Fe substitution in $\mathrm{CO}_{3} \mathrm{~S}_{4}$, although there are intermediate compositions along the Ni-rich portion of the $\mathrm{Ni}_{3} \mathrm{~S}_{4}-\mathrm{Fe}_{3} \mathrm{~S}_{4}$, join, including the mineral violarite $\left(\mathrm{FeNi}_{2} \mathrm{~S}_{4}\right)$. Ni-bearing greigite is found in nature but assumed to be metastable (Vaughan and Craig (1985)). Compositions near the centre of the $\mathrm{Ni}_{3} \mathrm{~S}_{4}-\mathrm{CO}_{3} \mathrm{~S}_{4}$ join (the siegenites) can contain significant substitutional $\mathrm{Fe}$ as $(\mathrm{NiCoFe})_{3} \mathrm{~S}_{4}$ (Vaughan et al. , 1971; Vaughan and Tossell, 1981; Wagner and Cook, 1999 and references therein).

Although $\mathrm{Ni}$ and Co substitution in synthetic greigite is limited, this has been related to differences in electronic structure with high spin Fe in both octahedral $\left(\mathrm{O}_{h}\right)$ and tetrahedral $\left(T_{d}\right)$ sites in greigite, whereas in $\mathrm{NiFe}_{2} \mathrm{~S}_{4}$ the octahedral $\mathrm{Fe} \mathrm{O}_{\mathrm{h}}$ is low spin (Vaughan et al., 1971; Vaughan and Craig, 1985; Lyubutin et al., 2013). The electrical properties of linneaite group minerals can vary although most have delocalised electrons which result in metallic conductivity and Pauli paramagnetism. Vaughan and Craig $(1981 ; 1985)$ found greigite is a semi-conductor with localized $3 d$ electrons having unpaired spins. However, many other authors declare greigite to be semimetallic in character and this property has been related to Fe-deficient non-stoichiometry and fast electron hopping between high-spin octahedral $\mathrm{Fe}^{2+}$ and $\mathrm{Fe}^{3+}$ atoms in the octahedral voids (Coey, 1970; Gibbs et al., 2007; Lyubutin et al., 2013).

The existence of non-stoichiometric greigite compositions (deviating from the ideal $\mathrm{Fe}_{3} \mathrm{~S}_{4}$ ) has also been suggested by other authors (Letard et al., 2005, Rickard and Luther, 2007; Bauer et al., 2013) and a stoichiometry of $\mathrm{Fe}_{2.994} \mathrm{~S}_{4}$ was determined for nano-greigite (Qian et al., 1999).

whereas the 18-nm- diameter nanoparticles behaved as stoichiometric $\mathrm{Fe}_{3} \mathrm{~S}_{4}$. However, it should be noted that neutron diffraction of similar greigite nanoparticles revealed no significant excess vacancy concentration or non-stoichiometry (Chang et al., 2009a). The 'possibility' of significant $\mathrm{Fe}^{4+}$ in greigite has also been suggested using bond length - valency estimates (Hoggins and Steinfink, 1976) that indicated an Fe valence of 3.92 for tetrahedral Fe sites (Gibbs et al., 2007). 


\section{Sample preparation.}

Various nanoparticle compositions were synthesised using diethyldithiocarbamato (DETC) compounds containing iron, nickel, cobalt and/or zinc (see Aktar et al., 2011 for precursor preparation) (Table 1). Two series were produced although for the relatively limited sample produced and examined in series 1, the experiments were not kept anaerobic. In series 2 the experiment was maintained anaerobic throughout and samples stored in a $N_{2}$ atmosphere until XAS/XMCD analysis; series 2 was extended to Zn-doped samples. For series 1 and 2, the greigite precursor was diethyldithiocarbamatoiron(III) $\left[\mathrm{Fe}\left(\mathrm{S}_{2} \mathrm{CN}(\mathrm{Et})_{2}\right)_{3}\right]$. Synthesis involved refluxing $15 \mathrm{ml}$ of oleylamine $\left(\mathrm{C}_{18} \mathrm{H}_{37} \mathrm{~N}\right)$ under vacuum at $90^{\circ} \mathrm{C}$ for 30 minutes, and then purging by nitrogen gas for 30 minutes. The precursor $\left[\mathrm{Fe}\left(\mathrm{S}_{2} \mathrm{CN}(\mathrm{Et})_{2}\right)_{3}\right]$ was added into the hot oleylamine, and the reaction temperature was slowly increased to $230^{\circ} \mathrm{C}$. The temperature was maintained for one hour in series 1 and 30 minutes in series 2, after which the mixture was then allowed to cool to room temperature. Addition of $30 \mathrm{ml}$ of methanol produced a black precipitate which was separated by centrifugation. The black residue was washed twice by methanol and re-dispersed in toluene or hexane for further characterisations. The $\mathrm{Ni}-, \mathrm{Zn}$ - and Co-doped greigites were synthesised by dietyldithiocarbamatoiron(III) combined with either dietyldithiocarbamatocobalt(II) $\left[\mathrm{Co}\left(\mathrm{S}_{2} \mathrm{CN}(\mathrm{Et})_{2}\right)_{3}\right]$ or dietyldithiocarbamatonickel(II) $\left[\mathrm{Ni}\left(\mathrm{S}_{2} \mathrm{CN}(\mathrm{Et})_{2}\right)_{3}\right]$ or dietyldithiocarbamatozinc(II) $\left[\mathrm{Zn}\left(\mathrm{S}_{2} \mathrm{CN}(\mathrm{Et})_{2}\right)_{3}\right]$ (using loadings reported in Table 1 ), in oleylamine at $230^{\circ} \mathrm{C}$; the synthesis then followed that for pure greigite (above). Greigite production was confirmed by PXRD (and TEM, Figure 2; $\mathrm{SI}, \mathrm{S} 2)$. Spectra were also collected on natural magnetite, $\mathrm{Fe}^{2+} \mathrm{Fe}_{2}{ }^{3+} \mathrm{O}_{4}$, from Kiruna, Sweden and the synthetic $\mathrm{Fe}^{3+}$-oxyhydroxides, goethite (FeO.OH) and ferrihydrite, $\left(\mathrm{Fe}^{3+}\right)_{2} \mathrm{O}_{3} \cdot 0.5 \mathrm{H}_{2} \mathrm{O}$, for comparison and energy calibration.

\section{Methods.}

X-ray absorption (XAS) spectra for Fe $L_{2,3}, \mathrm{Ni} L_{2,3}$ and $\mathrm{Co} L_{2,3}$ edges were collected on beamline 4.0.2 at the Advanced Light Source (ALS), Berkeley, CA, using the eight-pole magnet endstation (Arenholz and Prestemon, 2005). All Samples of greigite nanoparticles, and mineral standards were mounted in an anaerobic cabinet on carbon tape attached to the sample manipulator. Samples were kept anaerobic throughout insertion into the end-station vacuum. The X-ray beam is parallel to the magnetic field and along the sample normal. XAS was monitored in total-electronyield (TEY) mode, which gives an effective probing depth of $\sim 4 \mathrm{~nm}$. Energy calibration was 
undertaken using the standard magnetite with the main $L_{3}$ peak having a photon energy of $709 \mathrm{eV}$. At each energy point the XAS was measured for the two opposite magnetisation directions by reversing the applied field of $0.6 \mathrm{~T}$. The XAS spectra of the samples were normalised to the incident beam intensity and subtracted from each other to give the XMCD (see Pattrick et al. 2002; van der Laan and Figueroa, 2014 and references therein). All samples were initially measured under ambient conditions; most samples were subsequently cooled using a liquid $\mathrm{N}_{2}$ cryostat to 77 $\mathrm{K}$ and the XAS spectra measured for a second time, however no significant differences were observed between the spectra. The room temperature spectra are used in this study. Multiple spectra $(\geq 3)$ were taken to improve statistics at each elemental edge. The $\mathrm{Fe}, \mathrm{Co}$ and $\mathrm{Ni} L_{2,3}$ edge XAS and resulting XMCD were used to examine the electronic and magnetic structure of the materials. At the transition metal $L_{2,3}$ edge, the $2 p$ core electrons are excited by electric-dipole transitions into (partially) localised unoccupied $3 d$ states, so that XMCD provides information about the local electronic and magnetic structure of the absorbing atom (van der Laan and Thole, 1991; van der Laan, 2013). The spectrum is split by the $2 p$ spin-orbit interaction into two main structures, the $L_{3}$ and $L_{2}$ absorption edges.

The features of the Fe $L_{2,3}$ XMCD spectra obtained can be compared and differences due to substituting cations related to site occupancy. In the case of ferrite spinels quantitative information on site occupancies can be provided by comparison with calculated spectra (van der Laan and Thole., 1991; Pattrick et al., 2002). In these previous studies the Fe $L_{2,3}$-edge calculations the Hartree-Fock Slater integrals for the $3 d-3 d$ and $2 p-3 d$ Coulomb and exchange interactions were scaled to $70 \%$ and $80 \%$, respectively, and the crystal fields for the $\mathrm{O}_{\mathrm{h}}$ and $\mathrm{T}_{\mathrm{d}}$ sites were taken to be $10 D q=1.2 \mathrm{eV}$ and $-0.6 \mathrm{eV}$, respectively. The calculated and experimental studies of magnetite provide three distinct peaks representing the $\mathrm{Fe}^{2+} \mathrm{O}_{h}, \mathrm{Fe}^{3+} \mathrm{T}_{d}$ and $\mathrm{Fe}^{3+} \mathrm{O}_{h}$ sites (see Figure 4). The calculated Fe $L_{2,3}$-edge spectra were then convoluted by a Lorentzian of $\Gamma=0.3(0.5) \mathrm{eV}$ for the $L_{3}\left(L_{2}\right)$ edge to account for intrinsic core-hole lifetime broadening and by a Gaussian of $\sigma=0.2$ $\mathrm{eV}$ to account for the ALS instrumental broadening. In the current study, employing higher crystal fields is appropriate to take into account the relatively covalent nature of the greigite. Applying this methodology to greigite was important for comparison with ferrite spinels but, as discussed below, this modelling approach proved unsuccessful (see also Chang et al., 2012a). Examination of the XAS/XMCD of $\mathrm{Ni}$ and $\mathrm{Co} L_{2,3}$ reveals information about the oxidation state of these elements and demonstrates if these elements are in ferrimagnetic phases, pointing to substitution in the greigite. 
The bulk composition of the nanoparticles was determined by using electron probe microanalysis (EPMA) using a CAMECA SX100 at the Williamson Research Centre at the University of Manchester. Nanoparticles were pressed into carbon tape and analysed using a 5 micron beam at a beam current of $20 \mathrm{nA}$ and an accelerating voltage of $15 \mathrm{keV}$; Co, Fe, Zn, and Ni metal and $\mathrm{FeS}_{2}$ standards were used. The analyses provide low totals (ca $80 \mathrm{wt} \%$ ), typical of these type of samples and cannot be used to accurately define stoichiometry but the metal ratios are accurate to $<0.5$ wt\% and were recalculated assuming a formula of $\mathrm{Me}_{3} \mathrm{~S}_{4}$ to provide these metallic ratios (Abdulwahab et al., 2014).

Transmission electron microscope (TEM) imaging and electron diffraction was used to determine the size, shape, and crystal structure of the synthesised greigites. This was obtained using an FEI Tecnai G2 TEM with a $\mathrm{LaB}_{6}$ electron source operated at $200 \mathrm{kV}$. Energy dispersive X-ray (EDX) spectroscopy was performed using the Tecnai's Oxford Instruments XMax80 EDX detector with the obtained spectra being processed using the AzTec software. Images and diffraction patterns were processed using Gatan Digital Micrograph and ImageJ software. The JEMS Software package was used to simulate diffraction patterns for the structures (Stadelmann, 2003).

\section{Results}

\section{Nanoparticles}

\section{Results}

Powder X-ray diffraction analysis of all samples confirmed the production of crystalline greigite in all cases (pattern number 9000123). The EPMA analyses of the bulk greigite samples (series 2) revealed differences between the effectiveness of doping for different elements. The Ni doping was found to increase systematically in proportion to the initial starting composition up to $\simeq 16$ wt\% for Ni15\%, whereas the Co doping was found to saturate at 8 wt\% (Co10\% and Co15\% both have this same apparent concentration) and the Zn15 sample contains only $13 \mathrm{wt} \% \mathrm{Zn}$ (Table 1). TEM imaging confirmed the production of micro- and nano-crystals of greigite in all syntheses, with crystallites $<400 \mathrm{~nm}$ in diameter in all cases (Figure 2; S1, S2). The Co doped samples show considerably smaller nanocrystal dimensions than comparable $\mathrm{Zn}$ or $\mathrm{Ni}$ doped samples, with average diameters of $59 \pm 26 \mathrm{~nm}, 232 \pm 64 \mathrm{~nm}$, and $202 \pm 83 \mathrm{~nm}$ for Co 10, Ni 10 and Zn 10 samples (Figures 2 and S1, S2). In all cases the samples are polydisperse, with standard deviations 
44\%, 28\%, and $41 \%$ measured in the average diameter for Co $10, \mathrm{Ni} 10$ and $\mathrm{Zn} 10$ samples respectively. A range of morphologies were present, including the classic cubo-octahedral shapes (Beal et al., 2011; 2012; Lefevre et al., 2011) and, most commonly, plate-like pseudohexagonal shapes, consistent with nano-greigite produced by Han and Geo (2008). The Co and Zn doped crystals appear significantly more faceted than comparable $\mathrm{Ni}$ doped crystals, suggesting that the identity of the dopant affects both nanocrystal size and morphology. Selected area electron diffraction (SAED) patterns measured from all samples can be indexed to greigite (pattern number 9000123) regardless of the dopant with no other phases observed (Figure 2). TEM images and SAED patterns therefore suggest that the samples are all monophase and also that the particles are single crystals, both for pure $\mathrm{Fe}_{3} \mathrm{~S}_{4}$ and for the $\mathrm{Co}, \mathrm{Ni}$ and $\mathrm{Zn}$ doped greigites. HRTEM images of the Co doped greigite (Co10\%) also support the particles being single crystals (SI 2). EDX spectroscopy analysis of individual doped greigite crystals revealed no convincing evidence of elemental segregation..

\section{X-ray absorption spectroscopy.}

The Fe $L_{3}$-edge XAS spectra of aerobic greigite samples from Series 1 (Figure 3 ; 4 a) show two distinct peaks, at $708.15 \mathrm{eV}$ and $709.38 \mathrm{eV}$. In those samples with substituted Co and Ni the higher energy peak is manifest by a large shoulder at ca $709.15 \mathrm{eV}$ to the main $L_{3}$ intensity (Table 2, Figure 3 ) and this shoulder is less pronounced in the Co-doped samples than in the Ni samples. In contrast, all the anaerobically prepared samples (Series 2 ) display a single Fe $L_{3}$-edge peak intensity $707.60-707.90 \mathrm{eV}$; the $L_{2}$-edge is also a single peak at $720.50-720.81 \mathrm{eV}$ (Figure $4 \mathrm{a}$; Figure 5a). There was no difference between spectra collected at $293 \mathrm{~K}$ and $77 \mathrm{~K}$.

In previously published Fe $L_{3}$-edge spectra of greigite by Letard et al. (2005) and Chang et al. (2012a) two clear peaks are shown, with the higher energy peak being the most intense. This latter shoulder peak was linked to an iron oxide rim on the greigite particles (Letard et al., 2005) and it did not appear to contribute to the magnetic spectrum (Chang et al., 2012a). The peak at ca 709.2eV seen in the Series 1 greigites in this study is consistent with an $\mathrm{Fe}^{3+}$-oxide species when compared with Fe $L_{3}$-edge XAS spectra of likely products of Fe-sulfide oxidation such as goethite or ferrihydrite (Figure $4 \mathrm{~b}$ ). Considering the 3-4 $\mathrm{nm}$ penetration depth of the X-rays at the energy of the Fe $L_{2,3}$-edge, an oxide coating on the greigite particles would provide a major (non-magnetic) contribution to the XAS spectra. As the anaerobic samples in Series 2 show no intensity at $709 \mathrm{eV}$, we can presume that this is the true Fe $L_{2,3}$-edge XAS spectrum of greigite, particularly as the 
spectra are similar to the greigite produced by vapour-solid interaction deposition under vacuum in Bauer et al. (2013). Compared to magnetite Fe $L_{3} \mathrm{XAS}$, the greigite $\mathrm{Fe} L_{3}$ peak is narrower (0.8 eV at FWHM) and lacks the distinctive two components of the $L_{2,3}$ peaks (Figure 4c), although there is an indistinct shoulder at $706.2 \mathrm{eV}$ in greigite. While series 1 is useful to show the oxidation of the nanoparticles, the focus of this study on the unoxidised series 2 .

The Co $L_{2,3}$ XAS spectra of the anaerobic samples Series 2 (Figure 6b) show three features, a single peak at $779.1 \mathrm{eV}\left(L_{3}\right)$, a broad (satellite) intensity at $6.5 \mathrm{eV}$ higher which stretches over 4-5 eV, and a single $L_{2}$ peak at $794 \mathrm{eV}$ (Table 2). The spectra are similar to those derived from other Cosulfides, for instance in $\mathrm{CoS}_{2}$ and the thiospinel carrollite, $\mathrm{CuCO}_{2} \mathrm{~S}_{4}$, (Charnock et al, 1996; Pattrick et al., 2008). The satellites are due to Co $3 d^{6} \rightarrow 2 p^{5} 3 d^{7}$ transitions and it is interesting to note these are clearly visible in the Co10\% and Co15\% samples. The Ni $L_{2,3}$ XAS spectra of $\mathrm{Ni} 5 \%, \mathrm{Ni} 10 \%$ and $\mathrm{Ni15 \%}$ samples from Series 2 (Figure 5 a) all have similar spectral shapes, with single intensities for the $L_{3}$ and $L_{2}$ peaks at $852.8 \mathrm{eV}$ and $869.7 \mathrm{eV}$, respectively, with a broad (10 eV) low amplitude satellite intensity above the $L_{3}$-edge. These $\mathrm{Ni}$ spectra contrast with those derived from natural $\mathrm{NiFe}_{2} \mathrm{O}_{4}$ and $\mathrm{Ni}$-doped nanomagnetite (van der Laan et al., 1999; Coker et al., 2008) which both show a clear peak at ca. $2 \mathrm{eV}$ above the main peak $L_{3}$ peak and no satellite intensity.

\section{XMCD spectra.}

The Fe $L_{2,3}$ edge XMCD spectra for all the greigites are remarkably similar, doped and undoped, anaerobically and aerobically produced (Figure 5b, Figure 3 ). The spectra are similar to the single spectra of Chang et al. (2012a) and Letard et al. (2005), although in this study the fine structure is revealed by greater resolution. The whole $L_{3} X M C D$ spectrum has the same sign, with three distinctive 'negative peaks' identifiable (labelled A, C, E on Figure 4a) as well as two corresponding relatively positive features (labelled $B$ and D); all spectra also have a broad positive feature ca 711 $\mathrm{eV}$ which is a characteristic of covalent mixing with contributions from several configurations.

The Co $L_{2,3} X M C D$ spectra show little to no intensity (Figure $5 b$ ), revealing that the Co seen in the EPMA and TEM is present primarily as a non-magnetic component and that it is therefore unlikely to be doped in significant quantities substituted into the greigite lattice. Only if the affinity of $\mathrm{Co}^{2+}$ for tetrahedral and $\mathrm{Co}^{3+}$ for octahedral sites has led to an exactly equal split between the $\mathrm{A}$ and $\mathrm{B}$ 
sites (Vaughan and Craig, 1985; Coker et al., 2008) would substituted Co result in no net magnetic moment. The TEM analysis shows $\mathrm{Co}$ is associated with individual nanoparticles and the Fe in the aerobic particles is less oxidised suggesting a surface Co-S phase.

The Ni $L_{2,3}$ XMCD (Figure 5a), in contrast, shows single $L_{3}$ and $L_{2}$ peaks with opposite signs. As other potential $\mathrm{Ni}-\mathrm{S}$ phases that might form as rims on the nanoparticles such as $\mathrm{Ni}_{3} \mathrm{~S}_{4}$ and $\mathrm{NiS}$ are Pauli paramagnets, this is strong evidence that the $\mathrm{Ni}$ is incorporated in the greigite lattice. The $\mathrm{Ni}$ XMCD contrast with the $\mathrm{NiFe}_{2} \mathrm{O}_{4}$ and Ni-doped magnetite (van der Laan et al., 1999; Coker et al., 2008), lacking the broad positive intensity at a slightly higher energy than the main peak.

The Fe $L_{2,3}$-edge XMCD spectra of greigite is very different to that of ferrite spinels; the three peaks representing $\mathrm{Fe}^{2+} \mathrm{O}_{h}, \mathrm{Fe}^{3+} \mathrm{T}_{d}$ and $\mathrm{Fe}^{3+} \mathrm{O}_{h}$ in magnetite are absent (Figures 4c). Magnetite spectra can be modelled using multiplet calculations, however even with an increased crystal field, this methodology fails for greigite. A 'pseudo' fit to the measured XMCD spectrum can be achieved if the contribution of the $\mathrm{Fe}^{3+} \mathrm{T}_{d}$ component is set to zero. However, structural investigations indicate that greigite has a similar structure to magnetite (see Chang et al., 2009a,b and references therein) and the total absence of a tetrahedral component is an impossibility (Chang et al., 2012a).

The Fe $L_{2,3}$-edge XMCD spectra were analysed to investigate variations corresponding to $\mathrm{Co}, \mathrm{Ni}$, and $\mathrm{Zn}$ doping, and, if possible, relate these to site occupancy. Previous work has shown that Ni will preferentially occupy $\mathrm{O}_{h}$ sites and $\mathrm{Zn}$ into $\mathrm{T}_{d}$ sites in ferrite spinels; Co can occupy both sites (see Pattrick et al., 2002 and Coker et al., 2008 and references therein). Variations in the greigite spectra are small and to quantify these changes the relative intensities of the five peaks were calculated (see Table 3). The only trends involve Ni substitution in which the lowest energy peaks of the Fe $L_{3}$-edge (labelled A, B and C; Figure 4) decrease with higher dopant concentration, although all are more intense than unsubstituted greigite. As the $d^{6} O_{h}$ component is the lowest energy contribution to the spinel Fe $L_{2,3}$ XMCD spectra, this indicates that significant Ni occupies this site. Cobalt doping produces no detectable change in the Fe $L_{3}$ XMCD peak intensities, providing further evidence that Co was not substituted successfully into the greigite lattice. As the Co $L_{2,3}$ XAS spectra show the Co is present as a sulfide, and the ATEM shows this is distributed evenly across individual nanoparticles, a Co-S coating of the particles is confirmed. This would explain its resistance to oxidation in the aerobic samples, compared to pure greigite; a potentially useful property. 
The lack of observable $\mathrm{Zn} L_{2,3}$-edge XMCD spectrum from $\mathrm{Zn} d^{10}$ is well known and the $\mathrm{Zn}$ substitution into greigite indicated by the EPMA compositional data can only be determined from changes in the Fe $L_{2,3} X M C D$. The bulk Zn15\% nanoparticles contain ca 16 wt\% Zn suggesting either significant substitution of Fe for $\mathrm{Zn}$ or a similar coating of $\mathrm{Zn}-\mathrm{S}$ as discussed for the Codoped samples. In sample Zn5\% with $5.9 \mathrm{wt} \% \mathrm{Zn}$, peaks A, B and C show an increase with respect to undoped greigite but these peaks then decrease in the $16 \mathrm{wt} \% \mathrm{Zn}$ greigite (Zn15\%). A simple explanation for this behaviour is initial replacement of $\mathrm{Fe}$ in the $\mathrm{Fe}^{3+} \mathrm{T}_{d}$ site but with further substitution in the $\mathrm{Fe}^{2+} \mathrm{O}_{\mathrm{h}}$ site. However, given the affinity of $\mathrm{Zn}$ for tetrahedral coordination in sulfides, $T_{d}$ site occupancy is expected and $\mathrm{Zn}$ substitution into ferrite spinels leads to an endmember, normal spinel of composition $\mathrm{ZnFe}_{2} \mathrm{O}_{4}$ in which the $\mathrm{Zn}^{2+}$ mainly occupies the $\mathrm{T}_{d}$ site. In these $\mathrm{Zn}$ ferrite spinels limited initial $\mathrm{Zn}^{2+}$ substitution is focussed on the $\mathrm{T}_{d}$ site (A site) with attendant $\mathrm{Fe}^{2+} \mathrm{O}_{\mathrm{h}} \rightarrow \mathrm{Fe}^{3+} \mathrm{O}_{\mathrm{h}}$ in the $\mathrm{B}$ site; the net magnetic moment also increases (see Byrne et al., 2014). Further substitution into Zn ferrite spinels is more complex and B site - Oxygen - B site exchange interactions predominate, resulting in spin canting and eventually anti-parallel alignment of magnetic spins within the $\mathrm{B}$ site and loss of a magnetic moment in $\mathrm{ZnFe}_{2} \mathrm{O}_{4}$. A similar situation may exist in greigite at higher $\mathrm{Zn}$ concentrations leading to a loss in net magnetism.

\section{Discussion}

Significant substitution of $\mathrm{Ni}$ into the greigite nanoparticles is demonstrated, $\mathrm{Zn}$ substitution is implicated whereas there is no evidence of significant Co substitution. Vaughan and Craig (1985) argued that the more localised $3 d$ electrons and higher number of electrons in antibonding orbitals in greigite compared to violarite $\left(\mathrm{FeNi}_{2} \mathrm{~S}_{4}\right)$ means that the compositions between $\mathrm{Fe}_{3} \mathrm{~S}_{4}-\mathrm{FeNi}_{2} \mathrm{~S}_{4}$ will be metastable; indeed substitution along the $\mathrm{Fe}_{3} \mathrm{~S}_{4}-\mathrm{NiFe}_{2} \mathrm{~S}_{4}$ join is limited in natural samples (Vaughan et al., 1971; Wagner and Cook, 1999). However, the $12.7 \mathrm{wt} \% \mathrm{Ni}$ in the nanomaterials produced from an organic precursor in this study opens the possibility of tunable magnetic and electronic properties of greigite using $\mathrm{Ni}$ and probably $\mathrm{Zn}$. The lack of Co substitution contrasts with magnetite nanoparticles where Co occupies both tetrahedral and octahedral sites to produce $\mathrm{CoFe}_{2} \mathrm{O}_{4}$ (Coker et al., 2008). This lack of Co substitution in $\mathrm{Fe}_{3} \mathrm{~S}_{4}$ was also predicted (Vaughan et al. (1971), on grounds of differences in spin and antibonding electrons; there are also no known natural intermediate compositions in the $\mathrm{Co}_{3} \mathrm{~S}_{4}-\mathrm{Fe}_{3} \mathrm{~S}_{4}$ binary. 
The Fe $L_{2,3}$ XAS and XMCD spectra reflect the high conductivity of $\mathrm{Fe}_{3} \mathrm{~S}_{4}$ and the strong covalency of the Fe-S bonding in iron sulphides and, thus, sulphur plays an important role in the magnetic spectrum produced. Compared to $\mathrm{Fe}_{3} \mathrm{O}_{4}$, the $\mathrm{S}$ anion is much less electronegative than oxygen but the $\mathrm{Fe}$ is also less electropositive, the latter shown by the $\mathrm{Fe} L_{3} \mathrm{XAS}$ spectra of greigite at $\sim 0.5 \mathrm{eV}$ lower photon energy (Figures 3-5) than magnetite. This highly covalent character and semimetallicity arising from electron hopping between $\mathrm{Fe}^{3+}$ and $\mathrm{Fe}^{2+}$ on octahedral sites (see Vaughan et al., 1971; Dekkers et al., 2009) results in an intermediate oxidation state of the $\mathrm{Fe}$ in $\mathrm{O}_{\mathrm{h}}$ sites between $3^{+}$and $2^{+}$(effectively $\mathrm{Fe}^{2.5+}$ ). Indeed, for each site we should take into account the hybridization (mixing) between Fe $3 d^{n}$ and $3 d^{n+1} \underline{L}$ configurations, where $\underline{L}$ represents a hole on the sulfur. A strong hybridization can reduce the effective oxidation states of the Fe ion by about 0.5 eV. Furthermore, the higher conductivity of greigite means a high level of hopping between the two $\mathrm{O}_{\mathrm{h}}$ sites. On the timescale of the XAS process, there are two 'frozen' configurations (" $\mathrm{Fe}{ }^{2+\prime}$ and " $\mathrm{Fe}^{3+\prime}$ ) for magnetite, whereas for greigite the XAS sees only an average configuration over the two states. The lack of distinct " $\mathrm{Fe}^{2+} \mathrm{O}_{h}$ " and " $\mathrm{Fe}^{3+} \mathrm{O}_{h}$ " peaks and the presence of, effectively, "Fe $\mathrm{Fe}^{2.5+”}$ would also lead to a narrower overall XAS spectrum as seen for greigite. As electron transfer between the $A$ and $B$ sites is much less energetically favoured, the $\mathrm{Fe}^{3+} \mathrm{T}_{d}$ component will be largely preserved leading to an effective formula of $\left[\mathrm{Fe}^{3+} \uparrow\right]_{A}\left[2 \mathrm{Fe}^{2.5+} \downarrow\right]_{B} S_{4}{ }^{2-}$. It is worth noting these 'oxidation states' are not the chemical valences but the valences as seen in the XAS process, which samples the local valence state on the Fe site. Indeed a covalent bond in greigite can be described as a resonating valence state between $\mathrm{Fe}^{2+} \mathrm{S}^{2-}<->\mathrm{Fe}^{1+} \mathrm{S}^{1-}$.

The effect of $\mathrm{Fe}^{2.5+}$ on the XMCD spectrum would be to reduce the energy of the $\mathrm{Fe}^{3+} \mathrm{O}_{\mathrm{h}}$ component and increase that of the $\mathrm{Fe}^{2+} \mathrm{O}_{\mathrm{h}}$ component, producing an overlapping intermediate peak between 707.9 and $709.7 \mathrm{eV}$. Indeed the main (negative) peak (labelled E in Figure 4) in the measured greigite Fe $L_{3}$-edge XMCD spectrum is at ca $708.39 \mathrm{eV}$ (Table 2), which is also coincident with the expected positive intensity of the 'missing' $\mathrm{Fe}^{3+} \mathrm{T}_{d}$ component. Thus, the three XMCD contributions overlap resulting in the observed spectrum, and the contrast to magnetite (Figure 4). As the covalency of greigite contrasts strongly to the isostructural ferrite spinels, it is therefore impossible to simulate the greigite XMCD spectra using the method that has been successfully applied to magnetite where the $\mathrm{O}_{\mathrm{h}}$ cations conform to their nominal $2^{+}$and $3^{+}$oxidations states (Coker et al., 2008; 2009; Chang et al., 2012a). 
It is worth noting that pyrrhotite $\left(\mathrm{Fe}_{7} \mathrm{~S}_{8}\right)$, another of the rare ferrimagnetic sulfides at ambient temperatures also showed XAS/XMCD spectra, gives a good agreement with charge-transfer multiplet calculations which take into account a mixing between two different $3 d$ configurations (Letard et al., (2007). In pyrrhotite all the iron ions are in the $\mathrm{Fe}^{2+}$ ground state and strongly hybridized with sulphur ligands, which is confirmed by the XAS and XMCD signals at Fe and S $K$ edges which confirm the strong Fe-S hybridization and demonstrate the magnetic polarization of these hybridized states.

The effect of reduced anion electronegativity in Ni compounds is a decrease in near edge multiplet splitting seen in the XAS spectra of van der Laan et al. (1986) and the greigite $\mathrm{Ni} L_{2,3}$ XAS is similar to $\mathrm{Nil}_{2}$, the least electronegative compound in this previuos study. As only certain final multiplet states are accessible and individual contributions form discrete components in the XAS spectrum, the increasing hybridisation and the attendant multiplet splitting mean in $\mathrm{Nil}_{2}$ and $(\mathrm{Ni}, \mathrm{Fe})_{3} \mathrm{~S}_{4}$ these have 'merged' to form a single intensity. The positive satellite structures at $6 \mathrm{eV}$ above the main XAS $L_{3}$ edge is also a typical indicator of covalent bonding (van der Laan et al., 1986). As noted, the shape of the $\mathrm{Ni} L_{2,3}$ XAS and XMCD derived from greigite do not look at all like $\mathrm{Ni}^{2+}$ in an ionic solid (cf. van der Laan et al., 1999; Coker et al., 2008), lacking both the distinct shoulder in the XAS at 2 $\mathrm{eV}$ above the main $L_{3}$ peak, and a corresponding XMCD peak with an opposite sign to the main peak (Figure 6). The $\mathrm{Ni}$ appears, as with the Fe, to have strongly covalent character and the spectra indicate a lower oxidation state. In trevorite Ni has a ground state of $73 \% d^{8}$ character (the rest $d^{9}$ ) (van der Laan et al., 1999) whereas in $\mathrm{Nil}_{2}$ it is $47 \% d^{8}$. The similarity of the $\mathrm{Ni} L_{2,3}$ XAS spectrum of $\mathrm{Nil}_{2}$ to greigite supports an oxidation state close to $\mathrm{Ni}^{1.5+}$. The XMCD spectral changes and same sign for the $\mathrm{Ni}$ dichroism as the main $\mathrm{Fe} L_{3}$ greigite peak, indicate the $\mathrm{Ni}$ is in an octahedral site in greigite. Thus, the nominal formula can be written as $\left[\mathrm{Fe}^{3+} \uparrow\right]_{\mathrm{A}}\left[\left[(2-\mathrm{x}) \mathrm{Fe}^{2.5+} \downarrow\right]\left[\mathrm{Ni}_{\mathrm{x}}{ }^{1.5+}\right]\right]_{\mathrm{B}} \mathrm{S}_{4}{ }^{2-}$ although this requires $S$ to have a formal valency $<2$. Covalency and hybridisation is a long established feature of sulfides (Vaughan and Craig, 1978) and such a strong hybridization has been found in other $\mathrm{Ni}$-bearing sulfides such as $\left(\mathrm{Ni}_{0.1} \mathrm{Zn}_{0.9}\right) \mathrm{S}$ (Pérez-Dieste et al., 2004).

\section{Summary}

The covalency and nominal intermediate oxidation state of the $\mathrm{O}_{\mathrm{h}}$ site of $\mathrm{Fe}^{2.5+}$ are consistent with the XAS and XMCD spectra and also consistent with the magnetic moments of $3 \mu \mathrm{B}$ obtained by neutron scattering for the Fe in A and B sites (Chang et al., 2009a), lower than magnetite. The Ni substitution in these nano-greigites points to magnetic and electronic tunability which is under 
further investigation and even the apparent Co-coated greigite suggests potential development of particles resistant to oxidation. Zn substitution needs further investigation although the potential increase in net ferrimagnetism as Fe is concentrated on the octahedral B site, may suffer from the anti-parallel alignment of spins. It is also interesting to note that the Ni-doping in these nanoparticles supports the natural development of nano-Ni-bearing greigite, $\left(\mathrm{Fe}_{5} \mathrm{Ni}\right) \mathrm{S}_{8}$, which has been shown to catalyse biochemical reactions relevant to the origin of life at mid-oceanic ridge (Russell and Martin, 2004).

\section{REFERENCES}

Abdulwahab, KO, Malik, M.A., O'Brien, P. , Timco, G.A., Tuna, F., Muryn, C.A., Winpenny, R.E.P., Pattrick, R.A.D., Coker, V.S. and Arenholz, E. (2014) . A one-pot synthesis of monodispersed iron cobalt oxide and iron manganese oxide nanoparticles from bimetallic pivalate clusters. Chemistry of Minerals, 26, 999-1013.

Akhtar, M., Akhter, J., Malik, M.Z., O’Brien, P., Tuna, F, Raftery, J. and Helliwell M. (2011) Deposition of iron sulfide nanocrystals from single source precursors. Journal Materials Chemistry, 21, 9737-9745.

Arenholz, E. and Prestemon, S.O. (2005) Design and performance of an eight-pole resistive magnet for soft X-ray magnetic dichroism measurements. Review of Scientific Instrumentation. 76, 083908/1-8.

Bauer, E., Man, Ka, L., Pavlovska, P., Locatelli, A., Menteş, T.O., Niño, M.A. and Altman, M.S. (2014) $\mathrm{Fe}_{3} \mathrm{~S}_{4}$ (greigite) formation by vapor-solid reaction Journal Materials Chemistry, A, 2, 19031913.

Bazylinski, D.A., Frankel, R.B., Heywood, B.R., Mann, S., King, J.W., Donaghay, P.L. and Hanson, A.K. (1995). Controlled biomineralization of magnetite $\left(\mathrm{Fe}_{3} \mathrm{O}_{4}\right)$ and greigite $\left(\mathrm{Fe}_{3} \mathrm{~S}_{4}\right)$ in a magnetotactic bacterium. Applied Environmental Microbiology, 61,3232-3239.

Beal, J.H.L., Etchegoin, P.G. and Tilley, R.D. (2012) Synthesis and characterisation of magnetic iron sulfide nanocrystals. Journal of Solid State Chemistry, 189, 57-62. 
Beal, J.H.L., Prabakar, S., Gaston, N., Teh, G.B., Etchegoin, P. G., Williams, G. and Tilley R.D. (2011). Synthesis and comparison of the magnetic properties of iron sulfide spinel and iron oxide spinel nanocrystals. Chemistry of Materials., 23, 2514-2517.

Byrne, J.M., Coker V.S., Cespedes, E., Wincott, P.L., Vaughan, D.J., Pattrick, R.A.D., van der Laan, G., Arenholz, E., Tuna, F., Bencsik, M, Lloyd, J.R., and Telling, N.D. (2014) Biosynthesis of zinc substituted magnetite nanoparticles with enhanced magnetic properties. Advanced Functional Materials, 24, 2518-2529.

Chang., L, Pattrick, R.A.D., van der Laan, G., Coker, V.S. and Roberts, A.P. (2012a). Enigmatic X-ray magnetic circular dichroism in greigite, $\mathrm{Fe}_{3} \mathrm{~S}_{4}$. Canadian Mineralogist, 50, 667-674.

Chang, L.M., Rainford, B.D., Stewart, J.R., Ritter, C., Roberts, A.P., Tang, Y. and Chen, Q. (2009a), Magnetic structure of greigite $\left(\mathrm{Fe}_{3} \mathrm{~S}_{4}\right)$ probed by neutron powder diffraction and polarized neutron diffraction. Journal Geophysical Research, 114, B07101, 1-10.

Chang, L., Roberts, A.P., Rowan, C.J., Tang, Y., Pruner, P., Chen, Q. and Horng, C.S. (2009b). Lowtemperature magnetic properties of greigite $\left(\mathrm{Fe}_{3} \mathrm{~S}_{4}\right)$. Geochemistry Geophysics Geosystems, 10, Q01Y04,1-14.

Chang, L., Roberts, A.P., Tang, Y., Rainford, B.D., Muxworthy, A.R. and Chen, Q. (2008). Fundamental magnetic parameters from pure synthetic greigite $\left(\mathrm{Fe}_{3} \mathrm{~S}_{4}\right)$. Journal Geophysical Research, 113, B06104, 1-16.

Chang, Yo-S., Savitha, S., Sadhasivam, S., Hsu, C-K. and Lin, F-H. (2011) Fabrication, characterization, and application of greigite nanoparticles for cancer hyperthermia. Journal of Colloid and Interface Science, 363, 314-319.

Chang, L., M. Winklhofer, A. P. Roberts, M. J. Dekkers, C.-S. Horng,L. Hu, and Q. W. Chen (2012b), Ferromagnetic resonance characterization of greigite $\left(\mathrm{Fe}_{3} \mathrm{~S}_{4}\right)$, monoclinic pyrrhotite $\left(\mathrm{Fe}_{7} \mathrm{~S}_{8}\right)$ and non-interacting titanomagnetite $\left(\mathrm{Fe}_{3-\mathrm{x}} \mathrm{Ti}_{\mathrm{x}} \mathrm{O}_{4}\right)$, Geochemistry, Geophysics, Geosystems. 13, Q05Z41, 1-19. 
Charnock, J.M., Henderson, C.M.B., Mosselmans, J.F.W. and Pattrick, R.A.D. (1996). 3d transition metal L-edge X-ray absorption studies of the dichalcogenides of Fe, Co and Ni. Physics and Chemistry of Minerals, 23, 403-408.

Coey, J.M.D., Spender, M.R. and Morrish, A.H. (1970). The magnetic structure of the spinel, $\mathrm{Fe}_{3} \mathrm{~S}_{4}$. Solid State Communications, 8, 1605-1608.

Coker, V. S., Pearce, C. I., Pattrick, R.A.D., van der Laan, G., Telling N.D., Charnock, J. M. and Lloyd, J.R. (2008). Probing the site occupancies of $\mathrm{Co}-, \mathrm{Ni}-$, and $\mathrm{Mn}$-substituted biogenic magnetite using XAS and XMCD. American Mineralogist, 93, 1119-32

Coker, V.S., Telling, N.D., van der Laan, G., Pattrick, R.A.D., Pearce, C.I., Arenholz, E., Tuna, F., Winpenny, R. and Lloyd, J.R. (2009) Harnessing the extracellular bacterial production of nanoscale cobalt ferrite with exploitable magnetic properties, ACS Nano, 3, 1922-1928.

Dekkers, M.J., Passier, H.F. and Schoonen, M.A.A. (2000). Magnetic properties of hydrothermally synthesized greigite $\left(\mathrm{Fe}_{3} \mathrm{~S}_{4}\right)$ II. Hig- and low-temperature characteristics. Geophysical Journal International, 141, 809-819.

Devey, A. J., Grau-Crespo, R. and de Leeuw, N.H. (2009), Electronic and magnetic structure of $\mathrm{Fe}_{3} \mathrm{~S}_{4} . \mathrm{GGA}+\mathrm{U}$ investigation, Physical Reviews B, 79, 195126, 1-7.

Dunlop, D.J. and Özdemir, Ö. (1997), Rock Magnetism: Fundamentals and Frontiers,., Cambridge Univ. Press, Cambridge, U. K. 573 pp

Erwin, S. C., Zu, L., Haftel M. I., Efros, A. L., Kennedy, T. A. and Norris, D. J. -(2005) Doping semiconductor nanocrystals. Nature, 436, 91-94.

Frank, U., Nowaczyk, N.R. and Negendank, J.F.W. (2007) Geomagnetism, rock magnetism and palaeomagnetism of greigite bearing sediments from the Dead Sea, Israel. Geophysical Journal International, 168, 904-920.

Gibbs, G.V., Cox, D.F., Rosso, K.M., Ross, N.L., Downs, R.T. and Spackman, M.A. (2007). Theoretical electron density distributions for Fe- and Cu-Ssulfide Earth materials: A 
connection between bond length, bond critical point properties, local energy densities, and bonded interactions. Journal of Physics and Chemistry B, 111, 1923-1931.

Han, W. and Gao, M. (2008). Investigations on iron sulfide nanosheets prepared via a single-source precursor approach. Crystal Growth and Design, 8, 1023-1030.

Heywood, B.R., Mann, S. and Frankel, R.B. (1991). Structure, morphology and growth of biogenic greigite $\left(\mathrm{Fe}_{3} \mathrm{~S}_{4}\right)$. Materials Research Society Symposium Proceedings, 218, 93- 108.

Hoggins, J.T. and Steinfink, H.E. (1976) Empirical bonding relationships in metal-iron-sulfide compounds. Inorganic Chemistry, 15, 1682-1685.

Letard, I., Sainctavit' P., Cartier dit Moulin, C., Kappler, J-P., ,Ghigna, P., Gatteschi, D. and Doddi, D. (2007). Remnant magnetization of Fe8 high-spin molecules: X-ray magnetic circular dichroism at 300K. Journal Applied Physics, 101, 11392, 1-6.

Letard, I., Sainctavit, P., Menguy, N., Valet, J.-P., Isambert, A., Dekkers, M. and Gloter, A. (2005). Mineralogy of greigite, $\mathrm{Fe}_{3} \mathrm{~S}_{4}$. Physica Scripta, T115, 489-491.

Lefevre, C.T. Menguy, N., Abreu, F., Lins, U, , Pósfai, M. Prozorov, T., Pignol, D., Frankel, R.B. and Bazylinski, D.A. (2011). A cultured greigite-producing magnetotactic bacterium in a novel group of sulfate-reducing bacteria. Science, 334, 1720-1723.

Lewis, D. J., Tedstone, A. A., Zhong, X. I., Lewis, E. A., Rooney, A. I., Savjani, N, Brent, J. R., Haigh, S. J., Burke, M. G., Muryn, A., Raftery, J.M., Warrens, C., West, K., Gaemers, S. and O’Brien, P. (2015). Thin films of molybdenum disulfide doped with chromium by aerosol-assisted chemical vapor deposition (AACVD). Chemistry of Materials, 27, 1367-1374.

Lyubutin, I.S., Starchikov, S.S., Lin, C-R., Lu, S-Z., Shaikh, M.O., Funtov, K.O., Dmitrieva, T.V., Ovchinnikov S.G., Edelman, I.S. and Ivantsov, R. (2013). Magnetic, structural, and electronic properties of iron sulfide $\mathrm{Fe}_{3} \mathrm{~S}_{4}$ nanoparticles synthesized by the polyol mediated process. Journal Nanoparticles Research,15, 1397, 1-13. 
Mann, S., Sparks, N.H.C., Frankel, R.B., Bazylinski, D.A. and Jannasch, H.W. (1990).

Biomineralization of ferrimagnetic greigite $\left(\mathrm{Fe}_{3} \mathrm{~S}_{4}\right)$ and iron pyrite $\left(\mathrm{FeS}_{2}\right)$ in a magnetotactic bacterium, Nature, 343, 258-261.

Pattrick, R.A.D., Coker V. S., Pearce, C.I., Telling, N.D. and van der Laan, G. (2008). The oxidation state of copper and cobalt in carrollite, $\mathrm{CuCO}_{2} \mathrm{~S}_{4}$. Canadian Mineralogist, 46, 1317-1322.

Pattrick, R.A.D, Coker, V.S., Pearce, C.I., Telling, N.D., van der Laan, G. and Lloyd J.R. (2012) Extracellular bacterial production of doped magnetite nanoparticles. Nanoscience: Nanostructures through chemistry, 1, 102-111.

Pattrick, R.A.D., van der Laan, G., Henderson, C.M.B., Kuiper, P., Dudzik, E., Vaughan, D.J. (2002) Cation site occupancy in spinel ferrites studied by X-ray magnetic circular dichroism: Developing a method for mineralogists. European Journal of Mineralogy, 14, 1095-1102.

Pérez-Dieste, V., Crain, J.N., Kirakosian, A., McChesney, J.L., Arenholz, E., Young, A.T., Denlinger, J. D., Ederer, D. L., Callcott, T. A., Lopez-Rivera, S. A. and Himpsel, F. J. (2004). Unoccupied orbitals of $3 d$ transition metals in ZnS. Physcial Review B, 70, 085205, 1-5.

Pósfai, M., Cziner, K., Márton, E., Márton, P., Buseck, P.R., Frankel, R.B. and Bazylinski, D.A. (2001). Crystal-size distributions and possible biogenic origin of Fe sulphides. European Journal of Mineralogy, 13, 691-703.

Qian, X.F., Zhang, X.M., Wang, C., Xie, Y. Wang, W.Z. and Y. T. Qian (1999). The preparation and phase transition of nanocrystalline iron sulfides via toluene-thermal process, Materials Science and Engineering, 64, 170-173.

Reynolds, R.L., Tuttle, M.L, Rice, C.A., Fishman, N.S., Karachewski, J. A. and Sherman, D.S. (1994). Magnetization and geochemistry of greigite bearing Cretaceous strata, North Slope Basin, Alaska. American Journal Science, 294, 485-528.

Rickard, D. and Luther III, G. W. (2007). Chemistry of iron sulfides, Chemical Reviews, 107, 514562. 
Roberts A.P., Chang L., Rowan, C.J. , Horng, C-S. and Florindo, F. (2011) Magnetic properties of sedimentary greigite $\left(\mathrm{Fe}_{3} \mathrm{~S}_{4}\right)$ : An update. Reviews of Geophysics, RG1002, 1-46.

Roberts, A.P., Jiang, W.T., Florindo, F., Horng, C.S. and Laj, C. (2005). Assessing the timing of greigite formation and the reliability of the Upper Olduvai polarity transition record from the Crostolo River, Italy. Geophysical Research Letters, 32, L05307, 1-4.

Roberts, A.P. and Weaver, R. (2005). Multiple mechanisms of remagnetization involving sedimentary greigite $\left(\mathrm{Fe}_{3} \mathrm{~S}_{4}\right)$. Earth and Planetary Science Letters, 231, 263-277.

Roldan, A., Santos-Carballa, D and de Leeuw, N.H. (2013) A comparative DFT study of the mechanical and electronic properties of greigite $\mathrm{Fe}_{3} \mathrm{~S}_{4}$ and magnetite $\mathrm{Fe}_{3} \mathrm{O}_{4}$ Journal of Chemical Physics, 138, 204712.

Rowan, C.J., Roberts, A.P. and Broadbent, T. (2009), Paleomagnetic smoothing and magnetic enhancement in marine sediments due to prolonged early diagenetic growth of greigite. Earth and Planetary Science Letters, 277, 223-235.

Russell M.J., Hall, A.J, Boyce, A.J. and Fallick, A.E (2005). On Hydrothermal Convection Systems and the Emergence of Life. Economic Geology, 100 ,419-438

Russell M.J. and Martin, W. (2004) The rocky roots of the acetyl-CoA pathway. Trends in Biochemical Sciences, 29, 358-363.

Schoonen M.A.A. and Barnes H.L. (1991) Reactions forming pyrite and marcasite from solution: II. Via FeS precursors below $100{ }^{\circ} \mathrm{C}$. Geochimica et Cosmochimica Acta, 55, 1505-1514.

Schuler, D. and Frankel, R.B. (1999) Bacterial magnetosomes: microbiology, biomineralization and biotechnological applications. Applied Microbiology and Biotechnology, 52, 464-473.

Skinner, B.J., Erd, R.C. and Grimaldi, F.S. (1964) Greigite, the thio-spinel of iron; a new mineral. American Mineralogist, 49, 543-555. 
Snowball, I.F. and Torii, M. (1999) Incidence and significance of ferrimagnetic iron sulphides in Quaternary studies; in Quaternary Climates and Magnetism, editors Maher, B.A. and Thompson, R. Cambridge University Press, Cambridge, 199-230.

Stadelmann, P. (2003) Image Analysis and Simulation Software in Transmission Electron Microscopy. Microscopy and Microanalysis, 9, 60-61

van der Laan, G. (2013). Applications of soft x-ray magnetic dichroism. Journal of Physics, Conference Series, 430, 012127, 1-20.

van der Laan G. and Figueroa, A.I. (2014) X-ray magnetic circular dichroism - a versatile tool to study magnetism, Coordination Chemistry Reviews, 277-278, 95-129

van der Laan, G., Henderson, C.M,B, Pattrick, R.A.D, Dhesi S.S., Schofield, P.F., Dudzik, E. and Vaughan, D.J. (1999). Orbital polarization in $\mathrm{NiFe}_{2} \mathrm{O}_{4}$ measured by $\mathrm{Ni}-2 p$ x-ray magnetic circular dichroism. Physical Reviews B, 59, 4314-4321.

van der Laan, G. and Thole, B.T. (1991) Strong magnetic X-ray dichroism in $2 p$ absorption spectra of $3 d$ transition metal ions. Physical Reviews B, 43, 13401-13411.

van der Laan, G., Zaanen, J., Sawatsky, G.A., Karnatak, R. and Esteva, J-M. (1986) Comparison of Xray absorption spectroscopy with X-ray photoemission of nickel dihalides and NiO. Physical Review B, 33, 4253-4264.

Vanitha, P.V. and O'Brien P. (2008). Phase control in the synthesis of magnetic iron sulfide nanocrystals from a cubane-type Fe-S cluster. Journal of American Chemistry Society, 130, 1725617257.

Vasiliev, I., Franke, C., Meedijk, J.D., Dekkers M.J., Langereis, C.R. and Krijgsman, W. (2008). Putative greigite magnetofossils from the Pliocene epoch. Nature Geoscience, 1, 782 - 786.

Vaughan, D.J., Burns, R.G. and Burns V.M. (1971) Geochemistry and bonding of thiospinel minerals Geochimica et Cosmochimica Acta, 35, 365-381. 
Vaughan, D.J. and Craig, J.R. (1978) Mineral chemistry of metal sulfides. Cambridge University Press, Cambridge.

Vaughan, D.J. and Craig, J.R. (1985) The crystal chemistry of iron-nickel thiospinels. American Mineralogist, 70, 1036-1043.

Vaughan, D.J. and Tossell, J.A. (1981) Electronic structure of thiospinel minerals: Results from MO calculations. American Mineralogist, 66, 1250-1253.

Wagner, T. and Cook, N. J. (1999). Carrollite and related minerals of the linnaeite group: Solid solutions and nomenclature in the light of new data from the Siegerland district, Germany. Canadian Mineralogist, 37, 545-558.

Wang Y.S., Thomas P.J., O'Brien P (2006) Optical properties of ZnO nanocrystals doped with Cd, Mg, Mn, and Fe ions. Journal of Physical Chemistry B, 110, 21412-21415

Yamaguchi, S. and Wada H. (1970). Magnetic anisotropy of $\mathrm{Fe}_{3} \mathrm{~S}_{4}$ as revealed by electron diffraction, Journal of Applied Physics, 41, 1873-1874. 
Figure 1. The spinel structure showing the octahedral cation sites (small black spheres) the tetrahedral cation sites (small dark grey spheres), and the oxygen anions (light grey spheres) (Structure created using the programs Cerius and Weblife, Molecular Simulations Inc.)

Figure 2: TEM images (upper rows) and SAED patterns (bottom row) of greigite nanoparticles a) $\mathrm{Co}(10)$, b) $\mathrm{Ni}(10)$ and c) $\mathrm{Zn}(10)$ showing typical plate-like, single crystalline pseudohexagonal morphologies.

Figure 3. Fe $L_{2,3}$ XAS (left) and derived XMCD (right) spectra for aerobically prepared greigite and Ni and Co doped greigite. The dashed lines in the XAS spectra show the positions of the contribution from the greigite $(708 \mathrm{eV})$ and the oxide coating $(709.45 \mathrm{eV})$.

Figure 4. (a) Comparison of Fe $L_{2,3}$ XAS and (below) Fe $L_{2,3}$ XMCD of aerobically and anaerobically produced greigite; the XMCD peaks are normalised to peak $E$ (b) Fe $L_{2,3}$ XAS of ferrihydrite and goethite (c) Fe $L_{2,3}$ XAS and XMCD of nanomagnetite, the latter showing the three contributions at the $L_{3}$ edge due to $\mathrm{Fe}^{2+} \mathrm{O}_{\mathrm{h}}, \mathrm{Fe}^{3+} \mathrm{T}_{\mathrm{d}}$ and $\mathrm{Fe}^{3+} \mathrm{O}_{\mathrm{h}}$ (with increasing energy). The XMCD spectra have been increased $x 5$.

Figure 5. Fe $L_{2,3}$ XAS and XMCD spectra for anaerobically prepared nanogreigites (a) Fe $L_{2,3}$ XAS (b) Fe $L_{2,3} X M C D$.

Figure 6. (a) Ni $L_{2,3}$ XAS (top) and XMCD (bottom), the XAS and XMCD of trevorite $\left(\mathrm{NiFe}_{2} \mathrm{O}_{4}\right.$ ) are shown in red (b) Co $L_{2,3} X A S$ and XMCD in the anaerobically produced samples, the XAS and XMCD of Co-ferrite $\left(\mathrm{CoFe}_{2} \mathrm{O}_{4}\right)$ are shown in red. $\%=$ wt $\%$ starting compositions.

S1: Supporting information Figure 2. TEM size analysis histograms for Co10\%, Ni10\%, and Zn10\% samples, based on measurement of the diameters of 40 particles from each sample.

S2: Supporting information Figure 2. HRTEM image of Co10\% Nanocrystal. (a) with Fourier transform (b), nanocrystallites of all samples are believe to be predominantly single crystals. 
Table 1. Summary of synthesized greigite nanoparticles from diethyldithiocarbamato (DETC) compounds. showing loadings and bulk sample compositions defined by EPMA.

Series 1. Aerobic

\begin{tabular}{|l|l|l|l|}
\hline Phase & Precursors & $\begin{array}{l}\text { Loadings in } 15 \mathrm{ml} \\
\text { oleylamine }\end{array}$ & wt\% dopant \\
\hline Greigite & DETCiron(III) & $0.300 \mathrm{~g}, 0.59 \mathrm{mmol}$ & NA \\
\hline Ni-doped 5\% & DETCiron(III) & $0.300 \mathrm{~g}, 0.59 \mathrm{mmol}$ & - \\
& DETCnickel(II) & $0.010 \mathrm{~g}, 0.03 \mathrm{mmol}$ & \\
\hline Ni-doped 10\% & DETCiron(III) & $0.300 \mathrm{~g}, 0.59 \mathrm{mmol}$ & - \\
& DETCnickel(II) & $0.021 \mathrm{~g}, 0.06 \mathrm{mmol}$ & \\
\hline Co-doped 5\% & DETCiron(III) & $0.300 \mathrm{~g}, 0.59 \mathrm{mmol}$ & - \\
& DETCcobalt(II) & $0.010 \mathrm{~g}, 0.03 \mathrm{mmol}$ & \\
\hline
\end{tabular}

Series 2 Anaerobic

\begin{tabular}{|l|l|l|l|}
\hline Phase & Precursors & Loadings & $\begin{array}{l}\text { wt\% dopant } \\
\text { (EPMA) }\end{array}$ \\
\hline Greigite & DETCiron(III) & $0.300 \mathrm{~g}, 0.59 \mathrm{mmol}$ & NA \\
\hline $\begin{array}{l}\text { Ni-doped 5\% } \\
\text { Ni5\% }\end{array}$ & $\begin{array}{l}\text { DETCiron(III) } \\
\text { DETCnickel(II) }\end{array}$ & $\begin{array}{l}0.300 \mathrm{~g}, 0.59 \mathrm{mmol} \\
0.010 \mathrm{~g}, 0.03 \mathrm{mmol}\end{array}$ & 3.00 \\
\hline $\begin{array}{l}\text { Ni-doped 10\% } \\
\text { Ni10\% }\end{array}$ & $\begin{array}{l}\text { DETCiron(III) } \\
\text { DETCnickel(II) }\end{array}$ & $\begin{array}{l}0.300 \mathrm{~g}, 0.59 \mathrm{mmol} \\
0.021 \mathrm{~g}, 0.06 \mathrm{mmol}\end{array}$ & 9.97 \\
\hline $\begin{array}{l}\text { Ni-doped 15\% } \\
\text { Ni15\% }\end{array}$ & DETCiron(III) & $0.300 \mathrm{~g}, 0.59 \mathrm{mmol}$ & 16.51 \\
\hline $\begin{array}{l}\text { Co-doped 5\% } \\
\text { Co5\% }\end{array}$ & DETCnickel(II) & $0.031 \mathrm{~g}, 0.09 \mathrm{mmol}$ & \\
\hline $\begin{array}{l}\text { Co-doped10\% } \\
\text { Co10\% }\end{array}$ & DETCiron(III) & $0.300 \mathrm{~g}, 0.59 \mathrm{mmol}$ & 2.64 \\
\hline $\begin{array}{l}\text { Co-doped 15\% } \\
\text { Co15\% }\end{array}$ & DETCCobalt(II) & $0.010 \mathrm{~g}, 0.03 \mathrm{mmol}$ & \\
\hline $\begin{array}{l}\text { Zn-doped 5\% } \\
\text { Zn5\% }\end{array}$ & DETCcobalt(II) & $0.300 \mathrm{~g}, 0.59 \mathrm{mmol}$ & $0.021 \mathrm{~g}, 0.06 \mathrm{mmol}$ \\
\hline $\begin{array}{l}\text { Zn doped 15\% } \\
\text { Zn15\% }\end{array}$ & DETCcobalt(II) & $\begin{array}{l}0.300 \mathrm{~g}, 0.59 \mathrm{mmol} \\
0.031 \mathrm{~g}, 0.09 \mathrm{mmol}\end{array}$ & 8.83 \\
\hline
\end{tabular}


Table 2. Absorption energies of the main Fe $L_{2,3}$-edge peaks in the XAS spectra of greigite, doped greigite and magnetite. Italics = oxidised component of aerobically prepared greigite. Note that all greigite spectra have a shoulder at $706.2 \mathrm{eV}$ (Figure 4a; 5a).

\begin{tabular}{|c|c|c|}
\hline \multicolumn{3}{|c|}{ Anaerobic greigite } \\
\hline Sample & $L_{3}$ & $L_{2}$ \\
\hline Co5\% & 707.81 & 720.70 \\
\hline Co10\% & 707.60 & 720.58 \\
\hline Co15\% & 707.81 & 720.62 \\
\hline $\mathrm{Ni} 5 \%$ & 707.85 & 720.78 \\
\hline Ni $10 \%$ & 707.81 & 720.66 \\
\hline $\mathrm{Ni15} \%$ & 707.81 & 720.66 \\
\hline $\mathrm{Ni5 \%}$ & 707.85 & 720.78 \\
\hline Zn5\% & 707.85 & 720.81 \\
\hline Zn15\% & 707.60 & 720.50 \\
\hline Greigite (Gr) & 707.90 & 720.60 \\
\hline \multicolumn{3}{|c|}{ Aerobic greigite } \\
\hline Co5\% & $\begin{array}{l}708.03 \\
708.99\end{array}$ & 720.90 \\
\hline Co10\% & $\begin{array}{l}708.18 \\
709.38\end{array}$ & 721.01 \\
\hline $\mathrm{Ni5} \%$ & $\begin{array}{l}708.07 \\
709.03\end{array}$ & 721.01 \\
\hline $\mathrm{Ni10 \%}$ & $\begin{array}{l}708.07 \\
709.18\end{array}$ & 720.90 \\
\hline Greigite(Gr) & $\begin{array}{l}708.15 \\
709.38\end{array}$ & 720.90 \\
\hline \multicolumn{3}{|c|}{ Magnetite } \\
\hline MD2 & $\begin{array}{l}707.39 \\
709.00\end{array}$ & $\begin{array}{l}720.50 \\
721.80\end{array}$ \\
\hline
\end{tabular}


Table 3. Absorption energies of $C_{0} L_{2,3}$ edges in Co-doped, anaerobic nano-greigite and carrollite. The energy range of the satellite intensities is also given.

\begin{tabular}{|l|c|c|c|c|}
\hline Sample & $\boldsymbol{L}_{\mathbf{3}}$ & Satellite & Peak & $\boldsymbol{L}_{\mathbf{2}}$ \\
\hline Co XAS 5\% & 779.19 & - & 785.9 & 793.89 \\
\hline Co XAS 10\% & 778.99 & $783.5-787.9$ & 785.7 & 793.89 \\
\hline Co XAS 15\% & 779.24 & $783.7-788.1$ & 786.1 & 794.10 \\
\hline Carrollite $^{1}$ & 777.50 & $781.2-785.0$ & 782.2 & 792.2 \\
\hline
\end{tabular}

${ }^{1}$ From Pattrick et al. (2008)

Table 4. Absorption energies of $\mathrm{Ni} L_{2,3}$ edges in $\mathrm{Ni}$-doped, anaerobic nano-greigite. The energy range of the satellite intensities is also given.

\begin{tabular}{|l|c|c|c|c|}
\hline Sample & $\boldsymbol{L}_{\mathbf{3}}$ & Satellite & Peak & $\boldsymbol{L}_{\mathbf{2}}$ \\
\hline Ni XAS 5\% & 852.8 & $857.0-867.0$ & $(860.0)$ & 870.0 \\
\hline Ni XAS 10\% & 852.9 & $857.4-866.3$ & 859.5 & 870.0 \\
\hline Ni XAS 15\% & 852.7 & $856.4-867.0$ & 859.2 & 869.5 \\
\hline
\end{tabular}

Table 5. (a) Positions of the features in the XMCD spectra (Figure 4) and (b) the relative intensities of the peaks, assuming $980 \mathrm{eV}$ is 0 and normalising the main intensity, E, to 1.0.

\begin{tabular}{|l|l|l|l|l|l|}
\hline Peak & A & B & C & D & E \\
\hline Sample & & & & & \\
\hline Co5\% & 706.00 & 706.24 & 706.87 & 707.44 & 708.39 \\
\hline Co10\% & 705.88 & 706.18 & 706.75 & 707.38 & 708.31 \\
\hline Co15\% & 705.88 & 706.12 & 706.75 & 707.32 & 708.33 \\
\hline Ni5\% & 706.06 & 706.30 & 706.87 & 707.52 & 708.39 \\
\hline Ni10\% & 705.92 & 706.18 & 706.75 & 707.38 & 708.39 \\
\hline N15\% & 706.04 & 706.27 & 706.87 & 707.44 & 708.45 \\
\hline Zn5\% & 706.06 & 706.30 & 706.87 & 707.52 & 708.39 \\
\hline Zn15\% & 706.06 & 706.33 & 706.93 & 707.46 & 708.45 \\
\hline Gr & 706.06 & 706.30 & 706.91 & 707.50 & 708.39 \\
\hline
\end{tabular}

\begin{tabular}{|l|l|l|l|l|l|}
\hline Peak & A & B & C & D & E \\
\hline Sample & & & & & \\
\hline Co5\% & 0.277 & 0.250 & 0.501 & 0.234 & 1.00 \\
\hline Co10\% & 0.283 & 0.243 & 0.524 & 0.209 & 1.00 \\
\hline Co15\% & 0.289 & 0.245 & 0.512 & 0.161 & 1.00 \\
\hline Ni5\% & 0.360 & 0.317 & 0.564 & 0.256 & 1.00 \\
\hline Ni10\% & 0.334 & 0.282 & 0.545 & 0.154 & 1.00 \\
\hline N15\% & 0.307 & 0.259 & 0.488 & 0.248 & 1.00 \\
\hline Zn5\% & 0.339 & 0.284 & 0.596 & 0.257 & 0.999 \\
\hline Zn15\% & 0.220 & 0.216 & 0.505 & 0.316 & 1.004 \\
\hline Gr & 0.266 & 0.235 & 0.493 & 0.253 & 1.003 \\
\hline
\end{tabular}


